\title{
Effect Of Bevacizumab On Growth Of Human Nasal Polyposis In Vitro; An Off-Label Use Of Anti-Angiogenic Agent For Nasal Polyposis Treatment
}

Drug Design, Development and Therapy

\section{Shadman Nemati ${ }^{1}$ \\ Faeze Keihanian ${ }^{2,3}$ \\ Amin Saeidinia ${ }^{4,5}$ \\ Mahdi Bakhshaei ${ }^{6}$}

'Rhino-sinus, Ear, and Skull Base Diseases Research Center, Guilan University of Medical Sciences, Rasht, Iran; ${ }^{2}$ Cardiology Department, Imam Reza \& Ghaem Hospital, Faculty of Medicine, Mashhad University of Medical Sciences, Mashhad, Iran; ${ }^{3}$ Pharmaceutical Research Division, Booali Research Center, Mashhad University of Medical Sciences, Mashhad, Iran; ${ }^{4}$ Faculty of Medicine, Guilan University of Medical Sciences, Rasht, Iran; ${ }^{5}$ Pharmaceutical Research Division, Booali Research Center, Mashhad University of Medical Sciences, Mashhad, Iran; ${ }^{6}$ Faculty of Medicine, Ear, Nose and Throat Department, Mashhad University of Medical Sciences, Mashhad, Iran
Correspondence: Amin Saeidinia Faculty of Medicine, Mashhad University Complex, Azadi Square, Mashhad 9177948564 , Iran

Tel +9851I9119451607

Email saeidiniaa97I@mums.ac.ir
Introduction: Nasal polyposis (NP) is a frequent problem during adulthood. Treatment of NP is primarily based on drugs, such as oral or topical steroids and in some types, by surgery. Despite of available therapeutic options for NP, recurrence after polypectomy is found. Vascular endothelial growth factor (VEGF) is a known factor involved in NP. Bevacizumab is a monoclonal antibody, which acts against VEGF.

Aim: Regarding the availability of bevacizumab and its use in ophthalmic off-label application, in this study, we hypothesized that it could be a choice of non-invasive treatment. The researchers aimed at evaluating the use of bevacizumab in vitro on the growth of NP.

Materials and methods: In this experimental study, the researchers used eight non-allergic NP tissues from patients admitted for polypectomy clinic of Imam Reza Hospital, Mashhad. Tissues were cultured in DMEM medium based on standard protocols in the presence or absence of bevacizumab $(10$ to $250 \mu \mathrm{M})$ then incubated. The mean of the responses was reported. The level of VEGF and MTT test for NP epithelial cell viability were determined for each group. Data were analyzed using the SPSS software.

Results: The researchers demonstrated that bevacizumab leads to a decrease in the level of VEGF (the most common cause of angiogenesis in NP) in media culture of NP, dosedependently $(\mathrm{P}<0.001)$. The highest mean was related to the $10-\mu \mathrm{M}$ group and the least mean was related to the $250-\mu \mathrm{M}$ group. In MTT test after 5 days, it was shown that the percentage of viable epithelial NP cells (due to apoptosis) was decreased dose-dependently and could lead to resolving NP tissue $(\mathrm{P}<0.001)$, significantly.

Conclusion: This study showed that bevacizumab could help decrease the growth of NP tissue dose-dependently in organ culture in vitro by inhibiting VEGF. It seems that bevacizumab could be a good candidate for the treatment of non-allergic NP.

Keywords: nasal polyposis, non-allergic polyps, bevacizumab, Avastin, in vitro study

\section{Introduction}

The prevalence of nasal polyposis (NP) during adulthood is between $1 \%$ and $4 \%$ and in children, except in cases of cystic fibrosis, this is lower. It usually involves patients between 30 and 60 years old and is two to four times more frequent in males than females. ${ }^{1,2}$ Furthermore, NP is a chronic inflammatory disorder of nasal and paranasal sinuses mucosal membrane with unknown etiology. It is characterized by inflammatory edematous mucus mass that makes a wide or narrow stalk. ${ }^{3-5}$ 
NP tissue is covered by pseudo-stratified epithelium except some parts, which had squamous cells and basement membrane thickness. ${ }^{4}$ It is a multifactorial disorder that is associated with infection, inflammation without infection, and genetic and anatomic anomalies. There are some conditions related to NP, such as allergic and nonallergic rhinitis, fungal allergic sinusitis, aspirin intolerance, asthma, Churg-Strauss syndrome, cystic fibrosis, Kartagener syndrome, and primary ciliary dyskinesia. ${ }^{4}$ It has been determined that eosinophil infiltration, fibronectin expression, and edematous histology are associated with the size of NP. It has been indicated that eosinophil and fibronectin interaction may have a role in edema formation and lead to the growth of NP. ${ }^{6}$ Moreover, vascular endothelial growth factor (VEGF) is severely increased in NP mucosa. ${ }^{7}$ Precursor mRNA of tumor growth factor (TGF) and fibroblast growth factor (FGF) are increased in NP tissues. Immunohistochemistry analysis indicated that TGF- $\beta$ is accumulated in extra-cellular matrix and NP stroma, beside eosinophils. ${ }^{8}$ It has been demonstrated that TGF- $\alpha$, TGF- $\beta$, FGF, and epidermal growth factor induced the expression of VEGF, which is a known and strong factor in endothelial cell mitosis and vascular permeability. ${ }^{9}$ In another study, it was shown that in the nasal cavity, VEGF expression leads to angiogenesis and an increase in the vascular permeability. ${ }^{10}$

Furthermore, NP treatment is primarily oral or topical nasal steroids. Although in some cases that surgery is necessary, aggressive medical treatment is needed before and after surgery. ${ }^{11}$ The goal of treatment in NP is maintaining ventilation and discharge of sinuses, beside preventing its recurrence. ${ }^{4}$ Patients with abnormal endoscopic findings are tended to recurrence and will need greater surgical interventions in the future. ${ }^{3}$ Although there are many available options for treatment of NP, about $40 \%$ of patients that undergo polypectomy will encounter recurrence and need to re-surgery. ${ }^{2}$ It has been demonstrated that VEGF has an important role in angiogenesis of nasal polyp stalk. ${ }^{12}$ Bevacizumab (Avastin ${ }^{\circledR}$ ) is a long-term monoclonal antibody adjusted for humans and acts against VEGF. ${ }^{13}$ It has been approved for colorectal neoplasm treatment and is under-evaluation for breast and renal cancers treatment. ${ }^{14,15}$ It has also been used successfully for intra-vitreous injection to treat macular degeneration ${ }^{13}$ and proliferative diabetic retinopathy. ${ }^{16,17}$ This drug prevents the connection to VEGF and interaction by its receptors like KDR and Flt-1 in endothelial cells and prevents angiogenesis. $^{18}$
Regarding the high rate of NP recurrence after treatment, using an alternative treatment with high efficacy that can directly resolve the etiology of the disorder is necessary. Considering the important role of VEGF in etiology of NP formation, and no previous studies in this field, the current research was intended to explore this subject.

\section{Materials And Methods}

This study was designed to assess the effect of bevacizumab on the growth of NP culture.

\section{Subjects}

This research included patients, who were candidates for polypectomy and excluded those who had previously used intra-nasal corticosteroid, anti-histamine or anti-leukotriene, and intra-nasal decongestant or anti-cholinergic agents 1 week before the surgery. The research also excluded patients, who received intramuscular or oral steroid within 4 weeks before surgery, pregnant, and breastfeeding women. Eight subjects with non-allergic nasal polyps were recruited at the Department of Otorhinolaryngology, Mashhad University of Medical Sciences Imam Reza Hospital, Mashhad, Iran (Table 1). Individuals were diagnosed with nasal polyps based on the minimal criteria for chronic rhinosinusitis with nasal polyps, according to standard criteria. ${ }^{19}$

Nasal polyps were removed by surgery from the middle meatus at the beginning. No patients had been treated with steroids (systemic or topical), nonsteroidal antiinflammatory drugs, antihistamines or macrolide antibiotics for the 4 weeks prior to biopsy. Control nasal polyps were matched by age and gender with same condition as the intervention group.

\section{Organ Culture Of Nasal Polyp}

Nasal polyps were cultured using the air-liquid interface method. ${ }^{20}$ Eight nasal polyps were cut using blades into

Table I The Demographic Data Of Patients

\begin{tabular}{|l|l|}
\hline Variables & \\
\hline Age (years), mean \pm SD & $45.5 \pm 7.63$ \\
\hline Gender (male:female), frequency & $5: 3$ \\
\hline Type of polyp & \\
Asthma & $2,25 \%$ \\
Aspirin intolerance & $1,12.5 \%$ \\
Eosinophilic type & $5,62.5 \%$ \\
\hline
\end{tabular}


small pieces (about $3 \mathrm{~mm}^{3}$ ) under sterile conditions and passed through a fine wire mesh (pore size $0.9 \mathrm{~mm}^{3}$ ) to obtain tissue fragments. They were weighted and washed three times with phosphate-buffered saline containing amphotericin (Fungizone, $2.5 \mu \mathrm{g} / \mathrm{mL}$ ), streptomycin (100 $\mathrm{U} / \mathrm{mL})$, gentamycin $(100 \mathrm{U} / \mathrm{mL})$, and penicillin $\mathrm{G}(100 \mathrm{U} /$ $\mathrm{mL}$ ) and then rinsed with 98\% DMEM supplemented with calf serum $(10 \%)$ and gentamicin $(20 \mu \mathrm{g} / \mathrm{mL})$. Then, it was incubated for $1 \mathrm{hr}$. To determine the effects of Avastin (AryoGen Pharmed Co., Tehran, Iran) treatment on nasal polyps, tissues were saturated for $1 \mathrm{hr}$ in culture medium (DMEM $+10 \%$ calf serum $+100 \mu \mathrm{g} / \mathrm{mL}$ gentamicin, fungizone, streptomycin, and penicillin) in the presence or absence of Avastin $(10,50,100,150$, or $250 \mu \mathrm{M})$. Tissue fragments were then placed on hydrated $1 \times 1 \mathrm{~cm}$ gelatin sponge with the mucosa facing upward and the submucosa downward. Each sponge was placed in a 6-well plate containing $3 \mathrm{~mL}$ of culture medium so that the mucosa was above the liquid phase. The plates were then placed in an incubator and maintained at $37^{\circ} \mathrm{C}$ in a $5 \% \mathrm{CO} 2$ atmosphere for $24 \mathrm{hrs}$. Avastin $(10$ to $250 \mu \mathrm{M})$ was added to culture medium. Subjects were divided to six groups: 1) non-treated group (nasal polyps were saturated for $1 \mathrm{hr}$ in culture medium and then organ-cultured for $24 \mathrm{hrs}$ in culture medium); 2) $10 \mu \mathrm{M}$ Avastin-treated group; 3) 50 $\mu \mathrm{M}$ Avastin-treated group; 4) $100 \mu \mathrm{M}$ Avastin-treated group; 5) $150 \mu \mathrm{M}$ Avastin-treated group; 6) $250 \mu \mathrm{M}$ Avastin-treated group. Five cultures were performed by the samples in every group and the mean of results was considered for the report.

\section{Measurement Of VEGF}

The levels of VEGF were determined using a VEGF human ELISA kit (Cat. No. ab100663, Abcam, Cambridge, MA, USA). The detection limit was $10 \mathrm{pg} / \mathrm{mL}$.

\section{MTT Assay}

The tissue viability was assessed by measuring mitochondrial activity. Tissue $(20 \mathrm{mg})$ was incubated for $3 \mathrm{hrs}$ at $37^{\circ} \mathrm{C}$ with $2 \mathrm{mg} / \mathrm{mL}$ of MTT in DMEM. After removal of the medium and washing with PBS, tissues were incubated in $1 \mathrm{~mL}$ of Me2SO for 20 mins on a shaker to solubilize the formazan product. The OD was then measured spectrophotometrically at a $540 \mathrm{~nm}$. The OD was converted to percentage survival based on tissue before culture and expressed as relative viability (relative viability (\%) $=100 \times(\mathrm{OD}$ of $20 \mathrm{mg}$ of tissue after culture $/ \mathrm{OD}$ of $20 \mathrm{mg}$ of tissue before culture)). For each experimental condition, at least four experiments were performed using six replicates per experiment.

\section{Statistics}

Data were reported as mean \pm SD. Statistical differences were determined by ANOVA and Tukey's test using the SPSS software (ve.16; SPSS, Inc., Chicago, IL). P-values less than 0.05 were considered a significant difference.

\section{Ethics}

This study was approved by the ethical committee of Guilan University of Medical Sciences and ethical code of 1930252812 was assigned. Written informed consent was obtained from each patient. This study was conducted in accordance with the Declaration of Helsinki.

\section{Results}

The current findings showed that bevacizumab led to a decrease of VEGF level dose-dependently $(\mathrm{P}<0.001)$. The highest mean level of VEGF was associated with $10-\mu \mathrm{M}$ group and the least was associated with the $250-\mu \mathrm{M}$ group. The mean of VEGF in every group is listed in Table 2 and this dose-dependent effect is shown in Figure 1.

Table 3 demonstrates that the viable cell test by MTT showed the percentage of viable cells due to apoptosis after 5 days in isolated epithelial NP cells of different groups.

As shown in the above table, by increasing the days of study, the NP epithelial cells viability rate was decreased and bevacizumab significantly lowered the number of NP epithelial cells and improved the NP $(\mathrm{P}<0.001)$ (Figure 2).

Figure 3 shows the microscopic difference between highest dose bevacizumab versus the control group.

Table 2 The Mean Vascular Endothelial Growth Factor Level In Different Groups

\begin{tabular}{|l|l|l|l|l|l|l|}
\hline Group & Control & $\begin{array}{l}\text { Avastin } \\
10 \mu \mathrm{g} / \mathrm{mL}\end{array}$ & $\begin{array}{l}\text { Avastin } \\
\mathbf{5 0} \mu \mathrm{g} / \mathrm{mL}\end{array}$ & $\begin{array}{l}\text { Avastin } \\
\mathbf{1 0 0} \mu \mathrm{g} / \mathrm{mL}\end{array}$ & $\begin{array}{l}\text { Avastin } \\
\mathbf{1 5 0} \mu \mathrm{g} / \mathrm{mL}\end{array}$ & $\begin{array}{l}\text { Avastin } \\
\mathbf{2 5 0} \boldsymbol{\mu g} / \mathbf{m L}\end{array}$ \\
\hline $\begin{array}{l}\text { Mean VEGF level } \\
(\mathrm{pg} / \mathrm{mL})\end{array}$ & 285.3 & 243.1 & 198.4 & 161.3 & 58.5 & 49.8 \\
\hline
\end{tabular}




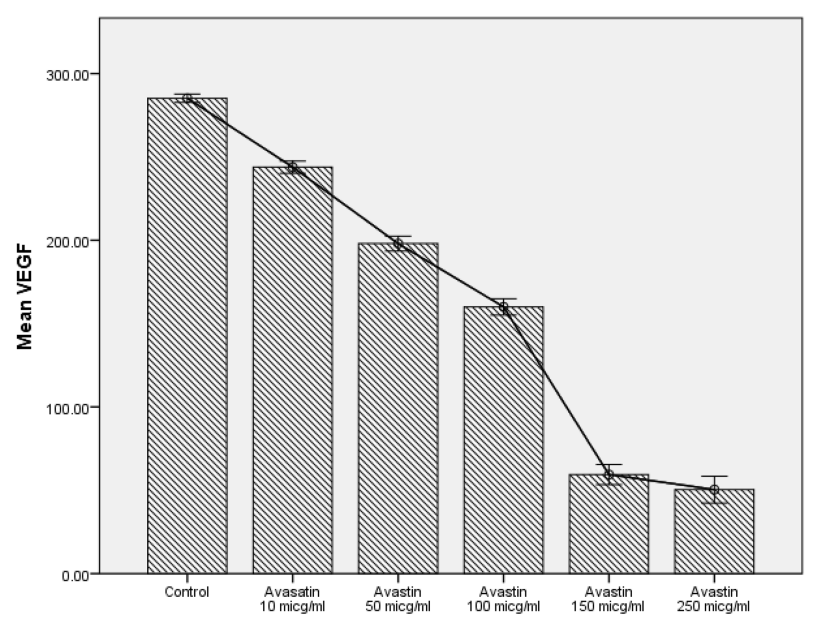

Figure I Effects of different doses of Avastin on vascular endothelial growth factor levels (measured by the ELISA method).

\section{Discussion}

To the best of the author's knowledge, this is the first study, in which the effect of off-label use of bevacizumab was evaluated in the treatment of NP. This study showed that bevacizumab markedly decreased the level of VEGF and resolved the NP cells in vitro culture.

The VEGF role in the regulation of angiogenesis has been the subject of intensive investigation over a decade. ${ }^{21}$ This not only leads to cellular growth, yet also prevents the apoptosis of epithelial cells. It acts in a forward positive route for automatic tuning by NP1 in non-neoplastic epithelial cells of human primary airways. ${ }^{22}$

The VEGF is the most important driver of vascular formation, as it is required to initiate the formation of new blood vessels by angiogenic sprouting or vasculogenesis. Furthermore, VEGF induces vascular hyper-permeability and angiogenesis through two high-affinity receptors: VEGFR-1, previously known as flt-1 (fms-like tyrosine kinase-1), and VEGFR-2, previously known as flk-1 (fetal liver kinase-1) or KDR (kinase-insert- domain-containing receptor). ${ }^{23,24}$ In nasal epithelial cells, VEGF can be a helpful factor for detecting nasal disorders. The function of VEGF can lead to an increase in hyperplasia of epithelial cells. Soluble VEGF in nasal lavage in NP increases and this increment is associated with the existence of NP. ${ }^{25}$ It has been demonstrated that VEGF is a novel biomarker for chronic rhinosinusitis with hyperplastic sinonasal polyposis that functions in an autocrine feedforward manner to promote nasal epithelial cell growth and to inhibit apoptosis. It functions through neuropilin-1 on non-neoplastic primary human airway epithelial cells, to amplify cell growth, contributing to exuberant hyperplastic polyposis. $^{25}$

Bevacizumab (Avastin ${ }^{\mathrm{TM}}$, Genentech) is a humanized monoclonal antibody targeting VEGF, a critical angiogenic factor involved in both physiological and pathological conditions. It has been approved by the US FDA as a first-line therapy for widespread metastatic colorectal cancer. The mechanism of anti-tumor activity of bevacizumab is most likely due to its anti-angiogenesis effect through binding and neutralization of secreted VEGF. ${ }^{21}$ Currently, bevacizumab is commonly used along with conventional chemotherapy in first-line treatment of metastatic colorectal cancer; however, it is used with only modest improvements in patient progression and overall survival when compared to chemotherapy alone. Furthermore, some patients do not benefit at all from this therapy. ${ }^{26}$ In vitro study of bevacizumab in different cancers has been performed and its effect through inhibition of VEGF was found previously. ${ }^{26-29}$ One of its adverse effect is nasal septum perforation, which should be considered.

Nasal application of bevacizumab is reported in limited literature. In a clinical trial study, its nasal use at dose of $100 \mathrm{mg}$ injected to nasal mucosa under sinus endoscopy reduced epistaxis in hereditary hemorrhagic telangiectasia. ${ }^{30}$ Some case reports indicated the use of bevacizumab as nasal spray or topical bevacizumab for epistaxis in hereditary hemorrhagic telangiectasia ${ }^{31-35}$ or Rendu-Osler disease. ${ }^{36}$ In an in vitro study, trans-mucosal bevacizumab transport through porcine nasal mucosa was confirmed harmless for nasal mucosa and no harm in histological assessment. ${ }^{37}$ In another clinical trial on epistaxis in hereditary hemorrhagic telangiectasia, a bevacizumab nasal spray treatment of three administrations at 14-day intervals with doses of $25 \mathrm{mg}, 50 \mathrm{mg}$, or $75 \mathrm{mg}$ per

Table 3 Viable Cell Test By MTT In Different Groups

\begin{tabular}{|c|c|c|c|c|c|c|c|c|c|c|c|c|c|c|c|c|c|c|}
\hline \multirow{2}{*}{$\begin{array}{l}\text { Group } \\
\text { Day }\end{array}$} & \multicolumn{3}{|c|}{ Control } & \multicolumn{3}{|c|}{$\begin{array}{l}\text { Avastin } \\
10 \mu \mathrm{g} / \mathrm{mL}\end{array}$} & \multicolumn{3}{|c|}{$\begin{array}{l}\text { Avastin } \\
50 \mu \mathrm{g} / \mathrm{mL}\end{array}$} & \multicolumn{3}{|c|}{$\begin{array}{l}\text { Avastin } \\
100 \mu \mathrm{g} / \mathrm{mL}\end{array}$} & \multicolumn{3}{|c|}{$\begin{array}{l}\text { Avastin } \\
150 \mu \mathrm{g} / \mathrm{mL}\end{array}$} & \multicolumn{3}{|c|}{$\begin{array}{l}\text { Avastin } \\
250 \mu \mathrm{g} / \mathrm{mL}\end{array}$} \\
\hline & I & 3 & 5 & I & 3 & 5 & I & 3 & 5 & I & 3 & 5 & I & 3 & 5 & I & 3 & 5 \\
\hline Viability (\%) & 100 & 100 & 100 & 72 & 67 & 56 & 58 & 52 & 45 & 54 & 49 & 43 & 49 & 41 & 36 & 47 & 34 & 27 \\
\hline
\end{tabular}




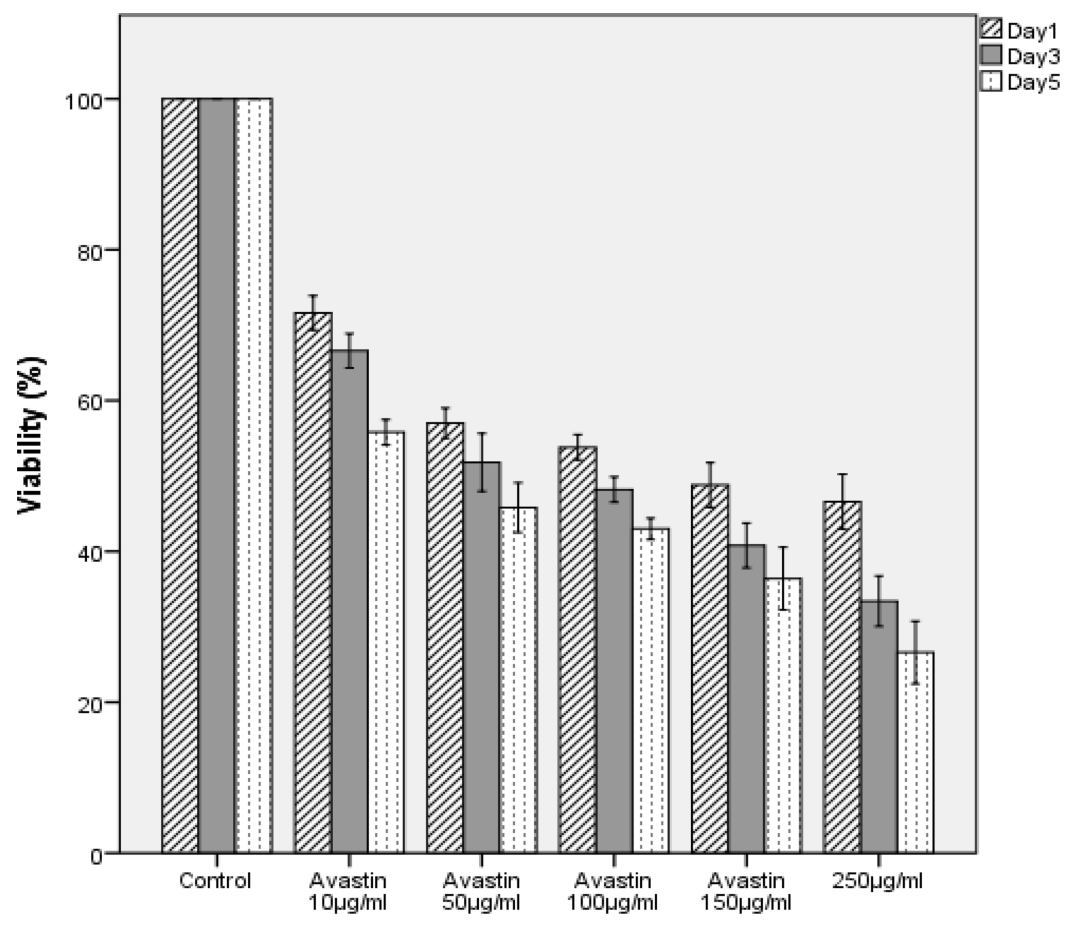

Figure 2 Effects of different doses of Avastin on nasal polyp epithelial cells in MTT test. It showed the lowering cell viability in polyp cells and significant dose-dependent decrease of volume of polyp size.
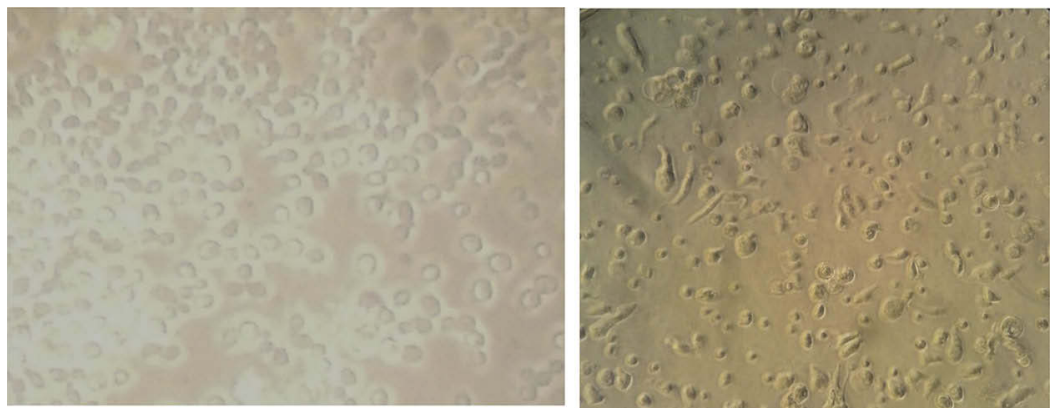

Figure 3 Control groups polyposis cell culture versus high dose of Avastin (250). The results showed a significant decrease of cell viability and deformation of nasal polyposis epithelial cells.

spray, compared with a placebo did not diminish epistaxis duration in the 3 repetitive months after the end of treatment. $^{38}$

However, there were no studies on its in vitro effect in NP culture. This is the first one and recommended its offlabel use for topical treatment of NP. According to the mechanism of the stalk of NP formation and the role of VEGF, the current findings supported the base of study for clinical trials in NP treatment. Due to available invasive treatments of NP and high rate of its recurrence, finding an effective therapeutic approach and lowering the size of NP by apoptosis and inhibiting VEGF expression is necessary. In previous studies in nasal application of bevacizumab, tolerance of its intranasal route was reported excellent after a 1-day nasal spray administration three times, regardless of the dose. Moreover, there was no side effect, such as nasal cartilaginous septum perforations. ${ }^{38}$ Topical treatment by bevacizumab might be a replacement choice for this disorder and decreases complications, cost of patients, and health systems. However, this needs greater explorations and clinical investigations.

The current study had some limitations: 1) we did not evaluate other inflammatory indexes in the culture media; 2) assessment of sub-groups of VEGF could help find mechanisms of the action of drug; 3 ) the researchers did not evaluate immunohistochemistry of the samples. 


\section{Conclusion}

This study showed that bevacizumab could help decrease the growth of NP tissue dose-dependently in organ culture in vitro by inhibiting VEGF and decrease epithelial NP cells survival. It seems that bevacizumab could be a good candidate for the treatment of non-allergic NP. However, performing clinical trials in human subjects should be performed. The current data provide evidence of the therapeutic effect of bevacizumab-treated NP cells by targeting VEGF for the first time.

\section{Abbreviations}

NP, nasal polyposis; VEGF, vascular endothelial growth factor; TGF, tumor growth factor; FGF, fibroblast growth factor; EGF, epidermal growth factor; flt-1, fms-like tyrosine kinase-1; flk-1, fetal liver kinase-1; KDR, kinaseinsert- domain-containing receptor.

\section{Acknowledgment}

The authors thank all the staff of Imam Reza Hospital for their cooperation in sample collection and Mr Feizi for his help with the NP culture.

\section{Disclosure}

The authors report no conflicts of interest in this work.

\section{References}

1. Settipane GA, editor. Epidemiology of nasal polyps. In: Allergy and Asthma Proceedings. Oceanside Publications; 1996;17(5):231.

2. Pearlman AN, Chandra RK, Conley DB, Kern RC. Epidemiology of nasal polyps. In: Nasal Polyposis. Berlin, Heidelberg: Springer; 2010:9-15.

3. Assanasen P, Naclerio RM. Medical and surgical management of nasal polyps. Curr Opin Otolaryngol Head Neck Surg. 2001;9(1):27-36. doi:10.1097/00020840-200102000-00007

4. Kirtsreesakul V. Update on nasal polyps: etiopathogenesis. $J$ Med Assoc Thailand. 2005;88(12):1966.

5. Nemati S, Mojtahedi A, Naghavi SE, Banan R, Zia F. Investigating Helicobacter pylori in nasal polyposis using polymerase chain reaction, urease test and culture. Eur Arch Otorhinolaryngol. 2012;269 (5):1457-1461. doi:10.1007/s00405-011-1848-8

6. Nakagawa T, Yamane H, Shigeta T, Takashima T, Nakai Y. Interaction between fibronectin and eosinophils in the growth of nasal polyps. Laryngoscope. 1999;109(4):557-561. doi:10.1097/00005537-1999040 00-00007

7. Cao Q, Zhang J. The expression and significance of STAT6, VEGF and MVD in Nasal Polyps. Cancer Res J. 2018;6(2):47. doi:10.11648/ j.crj.20180602.12

8. Haruna S, Nakanishi M, Otori N, Moriyama H. Histopathological features of nasal polyps with asthma association: an immunohistochemical study. Am J Rhinol. 2004;18(3):165-172.

9. Milanini J, Viñals F, Pouysségur J, Pagès G. p42/p44 MAP kinase module plays a key role in the transcriptional regulation of the vascular endothelial growth factor gene in fibroblasts. $J$ Biol Chem. 1998;273(29):18165-18172. doi:10.1074/jbc.273.29.18165
10. Muluk NB, Atasoy P, Arikan OK, Koc C. Role of vascular endothelial growth factor in the pathogenesis of nasal polyps. J Otolaryngol. 2007;36(6):357-366.

11. Bachert C, Zhang L, Gevaert P. Current and future treatment options for adult chronic rhinosinusitis: focus on nasal polyposis. J Allergy Clin Immunol. 2015;136(6):1431-1440. doi:10.1016/j.jaci.2015.10.010

12. Hu K-H, Lee F-P, Cheng Y-J, Huang H-M. Vascular endothelial growth factor and children featuring nasal polyps. Int $J$ Pediatr Otorhinolaryngol. 2007;71(1):23-28. doi:10.1016/j.ijporl.2006.08.018

13. Manzano RP, Peyman GA, Khan P, et al. Inhibition of experimental corneal neovascularisation by bevacizumab (Avastin). $\mathrm{Br} J$ Ophthalmol. 2007;91(6):804-807. doi:10.1136/bjo.2006.107912

14. Ferrara N, Hillan KJ, Novotny W. Bevacizumab (Avastin), a humanized anti-VEGF monoclonal antibody for cancer therapy. Biochem Biophys Res Commun. 2005;333(2):328-335. doi:10.1016/j.bbrc.2005.05.132

15. Miller KD, Chap LI, Holmes FA, et al. Randomized phase III trial of capecitabine compared with bevacizumab plus capecitabine in patients with previously treated metastatic breast cancer. $J$ Clin Oncol. 2004;23(4):792-799. doi:10.1200/JCO.2005.05.098

16. Avery RL. Regression of retinal and iris neovascularization after intravitreal bevacizumab (Avastin) treatment. Retina. 2006;26 (3):352-354. doi:10.1097/00006982-200603000-00016

17. Spaide RF, Fisher YL. Intravitreal bevacizumab (Avastin) treatment of proliferative diabetic retinopathy complicated by vitreous hemorrhage. Retina. 2006;26(3):275-278. doi:10.1097/00006982-200603000-00004

18. Sasich LD, Sukkari SR. The US FDAs withdrawal of the breast cancer indication for Avastin (bevacizumab). Saudi Pharm J. 2012;20(4):381-385. doi:10.1016/j.jsps.2011.12.001

19. Bachert C, Pawankar R, Zhang L, et al. ICON: chronic rhinosinusitis. World Allergy Organ J. 2014;7(1):1-28. doi:10.1186/1939-4551-7-1

20. Park SK, Lee WJ, Yang YI. Organ culture at the air-liquid interface maintains structural and functional integrities of inflammatory and fibrovascular cells of nasal polyps. Am J Rhinol. 2007;21(4):402407.

21. Wang Y, Fei D, Vanderlaan M, Song A. Biological activity of bevacizumab, a humanized anti-VEGF antibody in vitro. Angiogenesis. 2004;7(4):335-345. doi:10.1007/s10456-004-8272-2

22. Mygind N, Dahl R, Bachert C. Nasal polyposis, eosinophil dominated inflammation, and allergy. Thorax. 2000;55(suppl 2):S79-S83. doi:10.1136/thorax.55.suppl_2.s79

23. Wittekindt C, Hess A, Bloch W, Sultanie S, Michel O. Immunohistochemical expression of VEGF and VEGF receptors in nasal polyps as compared to normal turbinate mucosa. Eur Arch Otorhinolaryngol. 2002;259(6):294-298. doi:10.1007/s00405-002$0467-9$

24. Gosepath J, Brieger J, Lehr HA, Mann WJ. Expression, localization, and significance of vascular permeability/vascular endothelial growth factor in Nasal Polyps. Am J Rhinol. 2005;19(1):7-13.

25. Lee HS, Myers A, Kim J. Vascular endothelial growth factor drives autocrine epithelial cell proliferation and survival in chronic rhinosinusitis with nasal polyposis. Am J Respir Crit Care Med. 2009;180 (11):1056-1067. doi:10.1164/rccm.200905-0740OC

26. Zhao M, Yu Z, Li Z, Tang J, Lai X, Liu L. Expression of angiogenic growth factors VEGF, bFGF and ANG1 in colon cancer after bevacizumab treatment in vitro: a potential self-regulating mechanism. Oncol Rep. 2017;37(1):601-607. doi:10.3892/or.2016.5231

27. Zhang M, Chu S, Zeng F, Xu H. Bevacizumab modulates the process of fibrosis in vitro. Clin Exp Ophthalmol. 2015;43(2):173-179. doi:10.1111/ceo.12374

28. Terasaki H, Sakamoto T, Shirasawa M, et al. Penetration of bevacizumab and ranibizumab through retinal pigment epithelial layer in vitro. Retina. 2015;35(5):1007-1015. doi:10.1097/IAE.0000000000000428

29. Walraven M, Homs MYV, van der Veldt AAM, et al. Platelet function is disturbed by the angiogenesis inhibitors sunitinib and sorafenib, but unaffected by bevacizumab. Angiogenesis. 2018;21(2):325-334. doi:10.1007/s10456-018-9598-5 
30. Riss D, Burian M, Wolf A, Kranebitter V, Kaider A, Arnoldner C. Intranasal submucosal bevacizumab for epistaxis in hereditary hemorrhagic telangiectasia: a double-blind, randomized, placebocontrolled trial. Head Neck. 2015;37(6):783-787. doi:10.1002/hed. v37.6

31. Brinkerhoff BT, Choong NW, Treisman JS, Poetker DM. Intravenous and topical intranasal bevacizumab (Avastin) in hereditary hemorrhagic telangiectasia. Am J Otolaryngol. 2012;33(3):349-351. doi:10. 1016/j.amjoto.2011.07.012

32. Karnezis TT, Davidson TM. Treatment of hereditary hemorrhagic telangiectasia with submucosal and topical bevacizumab therapy. Laryngoscope. 2012;122(3):495-497. doi:10.1002/lary.22501

33. Chen S, Karnezis T, Davidson TM. Safety of intranasal Bevacizumab (Avastin) treatment in patients with hereditary hemorrhagic telangiectasia-associated epistaxis. Laryngoscope. 2011;121(3):644-646. doi:10. 1002/lary. 21345

34. Karnezis TT, Davidson TM. Efficacy of intranasal Bevacizumab (Avastin) treatment in patients with hereditary hemorrhagic telangiectasia-associated epistaxis. Laryngoscope. 2011;121(3):636-638. doi:10. 1002/lary. 21415
35. Rohrmeier C, Sachs HG, Kuehnel TS. A retrospective analysis of low dose, intranasal injected bevacizumab (Avastin) in hereditary haemorrhagic telangiectasia. Eur Arch Otorhinolaryngol. 2012;269 (2):531-536. doi:10.1007/s00405-011-1721-9

36. Guldmann R, Dupret A, Nivoix Y, Schultz P, Debry C. Bevacizumab nasal spray: noninvasive treatment of epistaxis in patients with Rendu-Osler disease. Laryngoscope. 2012;122(5):953-955. doi:10.10 02/lary. 23230

37. Samson G, Garcia de la Calera A, Dupuis-Girod S, et al. Ex vivo study of bevacizumab transport through porcine nasal mucosa. Eur $J$ Pharm Biopharm. 2012;80(2):465-469. doi:10.1016/j.ejpb.2011.11. 004

38. Dupuis-Girod S, Ambrun A, Decullier E, et al. Effect of bevacizumab nasal spray on epistaxis duration in hereditary hemorrhagic telangectasia: a randomized clinical trialbevacizumab nasal spray for epistaxis in patients with hhtbevacizumab nasal spray for epistaxis in patients with HHT. JAMA. 2016;316(9):934-942. doi:10.1001/jama.2016.11 387

\section{Publish your work in this journal}

Drug Design, Development and Therapy is an international, peerreviewed open-access journal that spans the spectrum of drug design and development through to clinical applications. Clinical outcomes, patient safety, and programs for the development and effective, safe, and sustained use of medicines are a feature of the journal, which has also been accepted for indexing on PubMed Central. The manuscript management system is completely online and includes a very quick and fair peer-review system, which is all easy to use. Visit http://www. dovepress.com/testimonials.php to read real quotes from published authors. 